\title{
Circumpolar Indigeneity in Canada, Russia, and the United States (Alaska): Do Differences Result in Representational Challenges for the Arctic Council?
}

\author{
Evgeniia Sidorova $^{1}$
}

(Received 1 May 2018; accepted in revised form 28 August 2018)

\begin{abstract}
This article investigates differences in circumpolar indigeneities in three major Arctic nations: Russia, Canada, and the United States (Alaska). Russia has different ways of recognizing indigeneity in law, and that definition of indigeneity excludes larger Indigenous groups of the Far North (Sakha, Komi), rather than seeing them as ethnic (titular) minorities. This study reveals that: 1) not all Indigenous peoples are represented in the Arctic Council; 2) there are historical explanations for this underrepresentation; 3) the Arctic Council should include more Indigenous groups as Permanent Participants. The equal representation of Indigenous organizations as Permanent Participants in the Arctic Council is important because all Indigenous groups in the Arctic should be heard.
\end{abstract}

Key words: Arctic Council; Indigenous peoples; representation; autonomy; Permanent Participants; indigeneity; Indigenous recognition

RÉSUMÉ. Cet article tente de déterminer s'il y a une différence entre les indigénéités circumpolaires de trois grands acteurs de l'Arctique, soit: la Russie, le Canada et les États-Unis (Alaska). En raison de la différence en matière de reconnaissance juridique de l'indigénéité en Russie, la définition de l'indigénéité exclut les grands groupes indigènes du Grand Nord (Sakha, Komi) et les considère plutôt comme des minorités ethniques (titulaires). Cette étude révèle que: 1) ce ne sont pas tous les peuples indigènes qui sont représentés au Conseil de l'Arctique; 2) cette sous-représentation s'explique par des raisons historiques; et 3) le Conseil de l'Arctique devrait inclure plus de groupes indigènes à titre de participants permanents. La représentation égale des participants permanents (organisations indigènes) au Conseil de l'Arctique est importante, car tous les groupes indigènes de l'Arctique devraient avoir la possibilité de se faire entendre.

Mots clés: Conseil de l'Arctique; peuples indigènes; représentation; autonomie; indigénéité; reconnaissance indigène

Traduit pour la revue Arctic par Nicole Giguère.

\section{DEFINING THE PROBLEM: WHO IS INDIGENOUS?}

The Arctic Council (AC) is the first intergovernmental forum to include Indigenous participants in the decisionmaking process. This was an important step in the understanding and recognition of Indigenous rights. However, it is hard to say whether all Indigenous groups in the Arctic are represented in the AC. A lack of Indigenous representation in the $\mathrm{AC}$ might be caused by differences in the legal systems of the Arctic states. The Russians perceive indigeneity differently from North Americans. According to some authors (Slezkine, 1994; Pika, 1999; Øverland, 2009), the Russian definition of indigeneity focuses on the size of the population, not on the fact of conquest. The Soviet Union had a practice of categorizing Indigenous groups in the North by separating smaller groups in the North from their more developed neighbours. The Komi and Sakha are circumpolar and Indigenous to their regions, but their population is larger than 50000 people (Slezkine, 1994; Pika, 1999; Øverland, 2009). The Russian Association of Indigenous Peoples of Siberia and the Far North (RAIPON) includes only legally recognized small Indigenous groups-those numbering fewer than 50000 people (RAIPON, 2019). According to federal laws, the list of Indigenous groups is established by the Government of the Russian Federation (Consultant Plus, 1999). This governmental decision to legally recognize only Indigenous groups with a population below 50000 people has had long-term consequences at the international level, such as the lack of recognition of larger Indigenous groups from the Far North (English, 2013).

The AC allowed Indigenous organizations to participate in the discussion of environmental issues as Permanent Participants (PPs) (Tennberg, 2000). Since the beginning, RAIPON, has participated in the $\mathrm{AC}$ as a PP representing small Indigenous groups of the Russian North. However, larger Indigenous groups of the Russian Far North, the Sakha and Komi, have never been represented in the AC, nor within RAIPON as PPs (RAIPON, 2019). In fact, the $\mathrm{AC}$ has never included all Indigenous participants from the Russian Far North.

${ }^{1}$ Department of Political Science, University of Calgary, Calgary, Alberta T2N 1N4, Canada; evgeniia.sidorova@ucalgary.ca

(C) The Arctic Institute of North America 
I analyzed three case studies - the United States (Alaska), Canada, and Russia-to support my argument that indigeneity in the Arctic is being defined by the member states, not by the international community. These case studies also illustrate that Indigenous identities were affected by historical circumstances as well as by governmental ideologies, and that there is no single definition or understanding of indigeneity in the Arctic.

\section{U.S. (Alaska)}

Because Alaska was ceded to the United States later than other American states and has always been a remote territory, Alaska Natives were recognized as Indigenous much later than Native Americans. After the purchase of Alaska from the Russian Empire, Article III of the 1867 Treaty of Cession provided a distinction between "uncivilized tribes" and the other "inhabitants of the ceded territory." The "uncivilized" category was determined either by Russian classification or by U.S. law (Anderson, 2007; Case and Voluck, 2012:165). Although the federal Indian legislation was applicable to Alaska Natives, their legal status was unclear until the beginning of the 20th century. Many federal statutes, such as the Indian Trade and Intercourse Act, were not applied to Alaskan lands until 1948. The 1884 Organic Act prevented Alaska Natives from making claims of Aboriginal title. Furthermore, because of the lack of a separate Native agency in Alaska, the Department of the Interior held that the federal government treated Alaska Natives differently from other Native Americans (Case and Voluck, 2012). Finally, in 1936, Congress issued amendments to the Indian Reorganization Act (IRA) in regard to Alaska that generally equated the legal status of Alaska Natives to that of Native Americans (Case and Voluck, 2012).

Anderson (2007) and Case and Voluck (2012) note that the amendments to the IRA were created to regulate government power and land ownership for Alaska Natives in the same ways as for Native American reservations. By 1941, the Department of the Interior had organized 75 Indigenous groups under the IRA amendments (Case and Voluck, 2012). These amendments were intended to identify Alaska Native communities according to the lands that they occupied. The organization of Alaska Native governments made their status equal with that of Indigenous governments generally. By the time of Alaska's statehood in 1959, both the courts and the Congress recognized the historical equality of Alaska Native governments' internal authority with Native governments in the lower 48 states (Case and Voluck, 2012). However, despite the clarification of the status of tribal governments in Alaska, the territory that fell under their jurisdiction was not clearly identified. Even though the IRA governments could deliver social services to their residents, they could not provide police, taxing, and other authorities simply because of the lack of clearly defined boundaries. Hence, the IRA Act was not enough to regulate the life of Alaska Natives (Case and Voluck, 2012).
The adoption of the Alaska Native Claims Settlement Act (ANCSA) significantly influenced the relationships between the Indigenous groups of Alaska and the government (Anderson, 2007; Case and Voluck, 2012). The amendments to ANCSA in 1988 ensured Alaska Natives' access to federal programs designed for Indigenous groups (Case and Voluck, 2012). However, the legal status of tribal governance in Alaska is not the same as in the rest of the country (Anderson, 2007; Case and Voluck, 2012). According to the U.S. Supreme Court interpretation, ANCSA effectively removed inherent tribal authority over land (Case and Voluck, 2012). As Anderson (2007) notes, the issue of tribal sovereignty was never seriously discussed. However, the tribal governments in Alaska are still able to provide social services to the residents of their communities (Case and Voluck, 2012). The Bureau of Indian Affairs (BIA) of the U.S. Department of the Interior deals with regulations pertaining to Alaska Natives. The criteria of indigeneity described by the BIA include several requirements: 1) to establish that the person has a lineal ancestor who is an Alaska Native; 2) if so, to identify which tribe he/she was affiliated with; and 3) to document the relationships to that ancestor (Case and Voluck, 2012).

\section{Canada}

Like Alaska Natives, the Canadian Inuit were recognized as an Indigenous group later than other communities, in this case First Nations and Métis. The British North America Act (BNA Act) made the federal government responsible for providing social services for the Indigenous peoples of Canada (Shadian, 2014). The Indian Act of 1876 authorized federal Indian Agents to oversee Indigenous peoples' activity in order to help them adapt to non-Indigenous society. Although Inuit were exempt from this Act, some of its provisions affected them as well. For instance, Inuit formed one of three Indigenous groups. The other two, First Nations and Métis, were forbidden to appeal against Canada without permission from the federal government in Ottawa. In 1939, the Supreme Court of Canada issued a decision that categorized Inuit as an Indigenous group of Canada. The BNA Act, the Indian Act, and further policies were based on the understanding of Indigenous peoples as backward (Shadian, 2014).

According to one of these policies, the 1941 Eskimo disc list system, each Inuit received a four-digit number engraved on a disc to be worn around the neck (Innuksuk, cited in Shadian, 2014). This process assigned family names and a district designation. The government attempted to keep track of each Inuk, and later attempted to administer government programs designed for the Inuit using this policy (Shadian, 2014). The Eskimo disc list system not only served to identify the Inuit, but also created criteria for their status that were generated entirely within a bureaucratic framework. Although the criteria designed by the Canadian government were based on racial descent and included marital status, cultural identification ("follows an Inuit 
way of life"), self-identification ("wishes to follow the Inuit way of life"), and acceptance of tribal members, the final decision was always made by the administration (Smith, 1993:65). Smith (1993:65) called Inuit status created by this policy an "inauthentic ethnic category." In other words, the government decided who is qualified to be an Inuk, instead of relying on tribal members and self-determination (Smith, 1993). The disc also automatically identified the Indigenous status of the owner. Smith gives an example of a man who was issued a disc as an Inuk, but subsequently had the disc taken from him because his father was not Inuit. At this time, he had lived most of his life as an Inuk, and wished to continue living this way. He asked for the disc to be returned to him, as he had lost the opportunities associated with the legal status of Inuit (Smith, 2003).

The global process of decolonization influenced the views of the Canadian government (Smith, 1993). In 1944, Ottawa created the Family Allowance program for all Canadians. According to the terms of this policy, Inuit could receive subsidies for the education of their children if they settled near a trading post or sent their younger children to residential schools. This program defined an Inuk as "a person who is listed as an Eskimo on the roll of records of, and to whom an identification disc has been issued by, the Bureau of Northwest Territories and Yukon Affairs of the Department of Mines and Resources" ("Family Allowances Regulations" cited in Smith, 1993:59). The 1947 Canadian Citizenship Act recognized Inuit as Canadian citizens. However, Inuit and other residents of Northwest Territories could not vote in federal elections until 1962 (Loukacheva, 2007).

After the Second World War, the Canadian government forced Inuit to move to permanent settlements in order to make social welfare accessible. By the mid-1960s, the Inuit population was concentrated around these settlements (Shadian, 2014). In 1969 the Canadian government issued the White Paper on Indian Policy, which rejected the former approach taken by the Indian Act. The White Paper was mostly aimed at assimilating Indigenous groups into mainstream Canadian society. First, land claims and treaties were rejected. Second, this act set up regular provincial agencies, instead of specialized bodies, to provide services for Indigenous groups. However, after the Calder decision in 1973, Aboriginal title was reaffirmed (Zellen, 2008). The Calder decision and the failure of the White Paper stimulated the formation of Inuit political associations. In 1976 Inuit Tapirisat of Canada (now Inuit Tapiriit Kanatami) asked the federal government to create Nunavut as a part of modernday treaties of Inuit land claims in the Northwest Territories. Finally, Canada's 1982 Constitution Act recognized Inuit as Indigenous people, distinct from First Nations people, giving them opportunities for land claims and self-governance (Zellen, 2008).

\section{Russia}

The history of colonization also affected the legal recognition of indigeneity by the Russian/Soviet governments. In fact, the legal definition of indigeneity in Russia was reconsidered after the October Revolution and deeply impacted by Communist ideology.

According to Slocum (1998:173), the term "inorodtsy," or "aliens," was introduced into Russian legislation in 1822 , when the Decree about the Governance over aliens was adopted. The term originated during the reign of Catherine the Great, when activities of the Crown intensified in Russian Asia. Although most of Siberia was attached to the Empire in the 16th and 17th centuries, the government began to consider a more "supple and pragmatic" policy only in Catherine's time (Slocum, 1998:178). The political views of Catherine, originally a Prussian princess, were strongly tied to the Enlightenment, when the transition to a sedentary lifestyle was considered a forward step in social evolution. The nomadic non-Russian groups of Siberia were differentiated from ethnic Russians in the eastern part of the Empire (Slocum, 1998).

It is also important to note that the history of Russian colonization of Siberia and the Far East affected the understanding of indigeneity. Øverland (2009) argues that, unlike North American colonization, Russia's influence in Siberia and the Far East did not occur at a particular moment in history. Russian colonization was gradual and took place over several hundred years (Øverland, 2009). Furthermore, by considering particular groups of peoples as Indigenous, the Soviet and then the Russian governments were giving special attention to small-numbered Indigenous groups and excluding groups from other parts of Russia, for instance, the Caucasus Mountains (Øverland, 2009). Small northern Indigenous groups were considered Indigenous (Slezkine, 1994).

The first attempts to regulate the status of Siberian nomads started after Catherine's death, when governorgeneral Mikhail Speransky returned to St. Petersburg after his service in Siberia. Speransky initiated this project in 1821 and finished it in 1822. The Decree on Aliens divided aliens into three categories: settled, nomadic, and wandering. The settled aliens were considered "civilized" in the same way as the general population. Thus, they obtained the same rights and responsibilities, and paid the same taxes (Slocum, 1998:179). Also, according to the Decree, nomads paid a fur tax (iasak) and local taxes; the wandering aliens paid only local taxes. The traditional tribal governance of nomadic and wandering aliens was introduced as a new structure of governmental institutions (Slocum, 1998).

Despite their settled status, Jewish people were also categorized as aliens, because of their non-Christian religious identity. Unlike Siberian aliens, Jews could not change their own alien status (Slocum, 1998). Overall, it is hard to say that the Russian Empire recognized Indigenous groups as a legal category. The term inorodtsy does not mean Indigenous or Native, but rather has a negative connotation related to being other, alien, from another clan, or even foreign (Slocum, 1998). This explains why the Jews were included in the same category. 
Although the Decree specified only one criterion for aliens - a settled way of life - in practice, several other factors also determined this status. These could be language (although Poles, Estonians, and Lithuanians were not Indigenous in the general sense, they spoke their Indigenous languages besides Russian), religion (Jews were non-Christians), and ethnicity (Siberian Indigenous groups were not Slavic). Even Ukrainians were often unofficially classified as aliens. This broad definition created a discussion about the determination of indigeneity in the Russian Empire. The Decree introduced non-Russian categories of partial rather than full Indigenous status. Slocum (1998) argues that the reason for this separation of non-Russians from the regular population was a fear of possible attacks on Moscow, which was still part of Russian memory. The language, religion, and ethnic differences of non-Slavic Russians were seen as foreign elements in the political body (Slocum, 1998).

After the October Revolution of 1917, the Decree about the Governance of Aliens was cancelled, along with other Imperial legal acts. The inception of Marxist ideology in society called for educational reform. According to the "father of nations," Joseph Stalin, "only the mother tongue can make possible a full development of intellectual faculties of the Tatar or of the Jewish worker" (Slezkin, 1994:418). Lenin suggested the construction of Marxist schools with the same curriculum, but with Indigenous teachers and Indigenous languages (Slezkine, 1994). The term inorodtsy (aliens) was excluded from the official language (Slocum, 1998).

These political views led to the policy called korenizatsiia (indigenization), introduced by the Soviet government during the 1920s (Slezkine, 1994; Xianzhong, 2014). Korenizatsiia gave non-Slavic populations privileges in education and employment (Slezkine, 1994). At the Tenth Party Congress, it was decided to give special assistance to non-Slavic groups because they had been oppressed as ethnic groups (Slezkine, 1994). The policy was presented as a "fixation of forced Russification" provided by Imperial Russia (Xianzhong, 2014:46). Korenizatsiia consisted of several steps: 1) preference for local people who spoke Indigenous languages and knew local traditions and customs to be elected in local governments; 2) adoption of special legislation that provided use of Indigenous languages everywhere in governmental bodies; and 3) construction of ethnic schools with a unified curriculum (Xianzhong, 2014).

Joseph Stalin's Marxism and the National Question (1913) supported Indigenous self-determination and promised to preserve the traditional culture and Indigenous cultures (Josephson, 2014). In opposition to the imperial policy, which mostly ignored the Indigenous population, the Soviet government organized the Committee of the North, with Peter Smidovich as head. Smidovich initiated the creation of the Institute of the People of the North, which conducted research on the culture, ethnography, history, and folklore of small Indigenous groups (Josephson, 2014).
After the 1920s the policy of korenizatsiia stopped. The government realized that supporting over 192 languages and bureaucracies across the country was overwhelming (Slezkine, 1994). Moreover, the central authorities became suspicious of the high level of ethnic nationalism all over the country. For instance, his compatriots considered Ukrainian poet Taras Shevchenko to be a genius, on a level with classic Russian writers such as Alexander Pushkin. Armenians pointed out that their culture was "one of the most ancient cultures of the east" (Slezkine, 1994:446).

In 1926 the Soviet government issued a statute that designated 26 groups as deserving state protection and special status. The government identified several criteria for them, including language, religion, traditional activities, and way of life (Donahoe et al., 2008). Because of the high concentration of ethnicities in eastern Russia, lawmakers also focused on additional factors such as small population, low population density, and remoteness from urban centers (Donahoe et al., 2008). In addition to requirements for indigeneity mentioned above, the Soviet government included a criterion of "backward" socioeconomic development (Slezkine, 1994). According to Marxist ideology, the socioeconomic development of humanity included several stages, and socialism was the desirable one. Thus, the state aimed to protect certain groups in order to stimulate their socioeconomic development (Donahoe et al., 2008).

Therefore, the policy of korenizatsiia was the main reason for the distinction of larger Indigenous groups from smaller ones. The larger nations were seen as closer to sovereign countries, with their own language, governance, and ethnic elite. Another reason for the legal identification of Indigenous groups could be their way of life-peoples that had what is known as a compact way of living: they were settled and less dispersed, had more chances to receive autonomous status and, thus, to be excluded from special governmental control and protection (Laruelle, 2013). This Soviet division between larger and smaller groups was copied by the Russian legislation (Laruelle, 2013).

Russian legislation uses a few criteria to identify ethnic groups as Indigenous groups, including lifestyle, livelihood, ethnic identity, and population. However, only population size is a relatively straightforward requirement in order for groups to be considered Indigenous in Russia. Groups with a population of less than 50000 can be considered as a smaller Indigenous people (Consultant Plus, 1999). Furthermore, larger ethnic groups that are Indigenous, including Sakha, Komi, or Chechens, are not included in this category because of their population size. Hence, larger ethnic groups could be considered as Indigenous in a broader sense; however, they are not accorded the same rights, benefits, or federal protection as the smaller groups. The list of the Arctic Indigenous minorities consists of 22 ethnicities, except Yakut (Sakha) (478085 members in the 2010 population census); Komis (and Komi-Permiaks) (329 111); and Karelians (60815) (Laruelle, 2013:36). There is also a possibility that some small Indigenous groups in Russia, such as the Nenets people, could lose their 
Indigenous status in the future as a result of increases in their population (Øverland, 2009).

In summary, despite significant differences in legal and political systems, Canada, the United States, and Russia created similar governmental policies that were aimed at protecting northern Indigenous groups from extinction (the Family Allowance Act, the Indian Reorganization Act, and korenizatsiia). The territorial remoteness of Indigenous groups in circumpolar North America and in Russia significantly affected their indigeneity, separating them not only from the dominant majority of white North Americans and Slavic Russians, but also from other Indigenous groups.

The most important difference between North American and Russian indigeneities lies in the evolution of Indigenous-state relationships and the nature of colonization. In comparison with colonization in Canada and the United States, that process in Siberia and the Far East was incremental and slow (Øverland, 2009). The main factor in recognizing small Indigenous groups as legally Indigenous in Russia had less to do with settlerIndigenous relationships than with the threat of extinction of Indigenous groups (Slezkine, 1994; Øverland, 2009; Laruelle, 2013).

\section{AUTONOMY OF NORTHERN INDIGENOUS GROUPS}

Indigenous peoples are unique because they are "exceptional," historically "other," and distinguishable. The experience of colonialism made them distinct in terms of their special rights on lands and autonomy (Lindroth, 2015:31).

\section{U.S. (Alaska)}

Alaska Natives joined the United States much later than Native Americans, at the time of the post-Civil War assimilation era of federal Native American policy. During this period, Native Americans were considered tribes that needed to be civilized, which meant that they had to be trained and educated to become part of mainstream society. This policy of assimilation also affected the lives of Alaska Natives when military officers came to Alaska in order to enforce federal customs and Native liquor laws (McBeath and Morehouse, 1994). The relationship between the U.S. government and Alaska Natives was influenced by the historical federal experience with Native Americans. From 1867 to 1912, before Alaska gained territorial status with an elected legislature, Congress did not consider Alaska Natives in the same way as Native Americans. They could not claim Aboriginal title or the same self-governing status as Indigenous people in the Lower 48. The Treaty of Cession of 1867 was signed as a result of the acquisition of Alaska from Russia. Article III of this treaty provided a distinction between the Russian inhabitants of Alaska and the Indigenous communities. Congress gave Russian settlers a choice to go back to Russia or stay in Alaska and obtain citizenship in the United States. The Indigenous people, however, were considered subject to such laws and regulations as the United States may, from time to time, adopt in regard to Aboriginal tribes in the lower states. However, Alaska did not have statehood until 1959, meaning Alaska Natives could not have the same rights as Native American tribes in the Lower 48. Thus, the treatment of Alaska Native tribes by the federal government could be divided into three periods: 1$)$ the early years $(1867-1934)$ noted above; 2) the middle period from the Indian Reorganization Act (1934) to the Alaska Native Claims Settlement Act (ANCSA) (1971); and 3) the post-ANCSA period (Bankes, 2008:128-129). The second period began when Congress applied the Indian Reorganization Act (1934) to Alaska Natives in 1936, whereby the United States was responsible for protecting Native-occupied lands in Alaska from acquisition by non-Natives. After the implementation of this Act, recognition of Alaska as a state continued this idea. The Alaska Statehood Act provided for the protection of lands occupied by "Indians, Eskimos, or Aleuts" from being taken over by the State of Alaska following statehood in 1959 (Case and Voluck, 2012:166). The Indigenous lands remained under the jurisdiction of the United States. In 1959, the U.S. Supreme Court case Tee-Hit-Ton Indians v. the United States confirmed that Alaska Natives could maintain a claim of Aboriginal title. At the same time, the Statehood Act granted the State of Alaska 104 million acres of land, which the state was eager to take over. Owing to controversy surrounding the question of Native ownership of much of the land in Alaska, the Secretary of the Interior decided to freeze Alaska's land selections until Native land claims were settled (Bankes, 2008). The third period began in 1971, when Congress adopted the ANCSA as a comprehensive settlement for Alaska Natives. ANCSA was called a law of stunning complexity; it vested ownership of about 45 million acres of land in 12 regional corporations, 200 village corporations, and nearly 75000 native residents, and paid nearly one billion dollars to the Alaska Native Fund (McBeath and Morehouse, 1994). The settlement dealt only with Alaska Native land claims, and did not include other Indigenous and environmental issues such as traditional resource harvesting, subsistence rights, or self-government. Therefore, ANCSA regulated the transfer of Native lands to Native-owned corporations, including oil and gas rights. ANCSA settled Alaska Natives Aboriginal land claims by awarding them fee simple title which granted them rights to own, occupy, and use the land they received. For the most part, the tribes selected lands in their traditional areas (Bankes, 2008). As owners of oil and gas rights, regional corporations obtained the right to participate in resource extraction and signed agreements with petroleum companies.

\section{Canada}

There had been a long treaty-making process between Indigenous groups and the British Crown before the 
recognition of Canadian statehood in 1867. The new Canadian government carried on this tradition until the 1920 s, but then the Parliament suspended the treaty-making process until the 1970s. Canada explained this decision by stating that the treaties with Indigenous communities were dictated by historical policy of the Crown, and they therefore were not the legal responsibility of the new government. Thus, new land claims agreements and negotiations were stopped (Bankes, 2008). However, the Calder decision of the Supreme Court of Canada in 1973 confirmed that Indigenous groups of Canada have ownership interest in their traditionally occupied lands. The position of the federal court in this case led to the acceptance of the legal concept of Indigenous title by the Canadian government and the creation of a negotiating structure with the Indigenous communities (Mason et al., 2008).

When Nunavut was created in 1999, Inuit leaders selected a public form of government instead of self-government. Thus, Nunavut has not been officially recognized as having Inuit self-government; there is public territorial governance for all inhabitants of the area (Loukacheva, 2007). As a senior official from Nunavut noted, "Nunavut looks like the Inuit government, because the Inuit are the majority right now, they control the government" (Loukacheva, 2007:40). Thus, the creation of Indigenous autonomy in Canada was primarily an Indigenous initiative, a bottom-up approach.

\section{Russia}

Unlike in Canada and the United States, the initiative of granting autonomy to Indigenous groups began with the Soviet government, which was guided by Marxist ideas of self-determination. By introducing the korenizatsiia reform, the Soviet Union granted autonomy and self-governance to some Indigenous groups. Adhering to Marxist ideology, the new Soviet government considered the principle of "ethnic particularism" as the opposite of capitalism; larger, dominant nations were perceived as tools of economic expansion (Slezkine, 1994:414). The government promoted the construction of the USSR as a large communal apartment in which national state units, various republics, and autonomous provinces represented "separate rooms" (Slezkine, 1994:415). This meant that each nation obtained the right to organize its life autonomously and to construct federal relations with other nations. The establishment of ethno-territorial autonomies for Indigenous groups seemed the best option for the implementation of this policy. Some nations were considered "backward" and others "civilized"; however, they were all considered equal to each other and had the same rights (Slezkine, 1994:421). Analyzing the degree of their "backwardness," the government decided which type of governance was needed in a particular autonomous unit. Some Indigenous groups, such as Sakha (Yakuts), received their own government because they "lived compactly" and were ready "to organize their lives through their own efforts" (Slezkine, 1994:421).
Therefore, despite the construction of ethnic governments within the country, the federal relationships in the Soviet Union de facto did not exist. As Stalin stated in the North Caucasus in 1920, autonomy does not mean separation but a union of the self-ruling mountain groups with the people of Russia (Kahn, 2002). Kahn (2002:70) argues that autonomy in the Soviet Union meant unification, not independence. Even the last leader of the USSR, Mikhail Gorbachev, publicly announced in 1989 that the Soviet Union was a centralized and unitary state, and that the Soviet people never lived in a federation (Ross, 2002). In other words, the Soviet Union granted nations cultural autonomy, territorial integrity, and symbols of statehood, while at the same time, the power of the central authority excluded any attempt by these subunits to operate separately from the unitary state.

The Russian Federation duplicated the structure of the Soviet Union in the logic of the hierarchy between nations, when larger ethnicities obtained the right to be considered as states, and smaller nations were recognized as nationalities and did not have the same privileges (Sakwa, 2008). Thirty-three ethnicities have their small homeland, and 63 do not. The groups that do not have homelands were included in other regions, without having their own ethnic republic (Sakwa, 2008).

Therefore, because of ideological and historical differences between the United States, Canada, and Russia, legal and political identities of Indigenous peoples, as well as their rights to autonomy, developed in distinct ways. By introducing ANCSA, the United States allowed Alaska Natives to have corporate bodies to control resource extraction on their lands. Canada dealt with Indigenous autonomies in a different way, by negotiating treaties and, as a result, giving the Inuit the right to govern Nunavut, which is largely Indigenous territory. Led by the Marxist ideology, the USSR and subsequently Russia, organized ethnic autonomies for larger populations of Indigenous peoples. These differences show that histories of colonialism affected legal recognition of Indigenous peoples by creating separate notions of indigeneity.

\section{THE ARCTIC COUNCIL AND PERMANENT PARTICIPANTS}

The $\mathrm{AC}$ is the intergovernmental forum that promotes cooperation and interaction among the countries in the Arctic region, Indigenous groups, and other Arctic residents. The AC facilitates the discussion on common issues in the Arctic, particularly on topics of sustainability and protection of the Arctic environment (AC, 2019). The creation of the $\mathrm{AC}$ was especially important under the pressure of growing environmental concerns in the Arctic, such as oil spills and contaminants in Arctic waters, as well as concerns over the rights of Indigenous groups, such as cultural survival and self-determination (Tennberg, 2000; English, 2013). The AC was a joint response of the Arctic 
states to these issues (English, 2013). The recognition of the concerns of Indigenous groups in the Arctic over environmental issues and self-determination by the state governments led to the discussion of direct involvement of Indigenous groups in decision-making processes in the Arctic (Tennberg, 2000). Unlike other international organizations, the AC accepted international Indigenous organizations in the discussion of political issues as PPs (Wilson and Overland, 2007). Indigenous organizations themselves noted that the status given to Indigenous groups in the $\mathrm{AC}$ is the highest ever granted to any Indigenous organizations in the world (Tennberg, 2000).

The idea of creating the $\mathrm{AC}$ was predominantly based on a bottom-up principle (the process advanced by civil society as opposed to the top-down approach driven by national elites [Keskitalo, 2004]) and primarily focused on the discussion of environmental issues and Indigenous groups (Keskitalo, 2004; Knecht, 2017). Following the bottom-up approach, the institutional design of the AC brought together not only circumpolar state actors, but also Indigenous groups and regional governments, as well as non-Arctic states (Keskitalo, 2004). Since the beginning of modern international cooperation in the Arctic following Gorbachev's 1987 Murmansk Speech, Indigenous involvement in policy-making processes was encouraged by many Arctic states, including Finland, the United States, Denmark, Canada, and Russia (Tennberg, 2000; Nilsson, 2009; English, 2013).

The issue of Indigenous participation was first discussed at the Arctic Environmental Protection Strategy (AEPS) consultative meeting in Rovaniemi in 1989, where the need to involve Indigenous groups in Arctic cooperation was driven by their negative experience of environmental pollution (Tennberg, 2000). Moreover, the participation of Indigenous actors was built into the structure of the AC because it was assumed that Indigenous participation could better address the existing issues in the Arctic (Keskitalo, 2004; English, 2013).

After a few meetings with Indigenous communities and governmental officials, the AEPS produced a draft declaration on the establishment of the Council that included international Indigenous organizations in the Arctic as PPs in the work of the forum (English, 2013). Indigenous organizations received the status of permanent observers during the negotiations of the AEPS in 1991, and the status of PPs when the AC was established (Huebert, cited in Keskitalo, 2004).

The Ottawa Declaration set up two criteria for PPs. Arctic Indigenous organizations with a majority Arctic Indigenous constituency are eligible to become PPs if they represent: 1) a single Indigenous people resident in more than one Arctic state; or 2) more than one Arctic Indigenous people resident in a single Arctic state (AC, 1996).

The formal role of Indigenous groups as PPs allowed them involvement in decision-making processes and knowledge production (Tennberg, 2000; Nilsson, 2009). As a result, the uniqueness of the internal organization of the AC significantly influenced the definition of legitimate knowledge regarding climate change in the discussion of the 2004 Arctic Climate Impact Assessment (ACIA). The PP mechanism of the AC was used during the 2002 World Summit on Sustainable Development (WSSD) as a model that incorporates principles of genuine partnership between states and Indigenous groups (Heinamaki, 2009). The PP model provides a unique opportunity to Indigenous groups in the Arctic to be heard and to participate in the governance of the international Arctic region. Otherwise, without state status, Indigenous organizations are usually defined as non-governmental organizations (NGOs) and have very constrained participation rights in the international decision-making process (Tennberg, 2009).

Since 1991, three major Indigenous organizations have been included in international cooperation in the Arctic: the Inuit Circumpolar Council (ICC), the Sami Council, and the Russian Association of Indigenous Peoples of the North (Tennberg, 2000; AC, 2019). Subsequently, these organizations were recognized as PPs in the Declaration on the Establishment of the AC (AC, 1996). The question of adding more PPs in the $\mathrm{AC}$ for more comprehensive representation was raised a few times. It was decided that the number of PPs should, at any time, be less than the number of member states (AC, 1996).

However, despite the success of the participation of the PPs, the issue of their representation has been difficult from the beginning (Tennberg, 2000). Some Indigenous groups in Canada and Russia, such as the Dene and the Yakut, felt that they were not represented by any organization (Tennberg, 2000). At the same time, the Canadian delegation noted that the PP category is meant "exclusively for Indigenous organizations," so national delegations could not include Indigenous groups as members (Tennberg, 2000:40). Because of the lack of clarity regarding the eligibility of Indigenous organizations, the Russian delegation could not decide how many additional groups can qualify as PPs (Tennberg, 2000). The discussion about the actual representativeness of PPs was also raised by Håken Nilson (1997) from the Norwegian Polar Institute in his study of the AEPS and its working groups (Nilson, 1997). During the AEPS meeting in Norway in 1997, Nilson's (1997) report was attacked by the ICC (English, 2013). His report included the questions "How representative are the three IPO Permanent Participants?" and "Have they squeezed out other Arctic stakeholders, have they taken over the agendas of other groups?" (Nilson, 1997:49). In response to Nilson's questions, the Canadian and Danish/Greenlandic delegations supported the ICC and the existing PPs (English, 2013). The minutes of the meeting reported that "the questions from the consultant had been a mistake," and it was noted that they had not been sent to Canadian officials (English, 2013:246).

The ICC suggested that the number of Indigenous organizations in the $\mathrm{AC}$ should be finite even though many more organizations were interested in being involved as PPs (Tennberg, 2000). According to the declaration on 
the establishment of the $\mathrm{AC}$, the number of PPs cannot be more than the number of states (Tennberg, 2000). In the beginning of international cooperation among the Arctic states, only three Indigenous organizations had PP status, but subsequently the list was extended by the admission of the Aleut International Association (1998), the Arctic Athabaskan Council, and the Gwich'in Council International (2000) (Tennberg, 2000; English, 2013; Knecht, 2017).

The literature has also noted that Indigenous actors are very dependent on their domestic governments both legally and financially (Tennberg, 2000; Wilson and Øverland, 2007; Ingimundarson, 2014). Tennberg (2009) claims that Indigenous organizations in the Arctic formed a political agency that is based on power relations between states and Indigenous groups. Indigenous nationalism is limited by the principles and concepts of sovereignty, statehood, and Indigenous rights of self-determination (Loukacheva, 2007). By using coercion, states can affect the activities of Indigenous organizations. In 2012, the Russian government suspended the activities of RAIPON for one year; in another case, the Greenlandic government boycotted the AC because it did not receive full access to the 2013 Kiruna Ministerial Meeting (Byers, 2013; Ingimundarson, 2014). Indigenous organizations and state actors are unequal in terms of their participation. Unlike states, PPs do not have the right to vote, so their effectiveness is based on the concept of influence (Wilson and Øverland, 2007). According to Wilson and Øverland (2007), the inclusion of PPs in the AC provided the opportunity for states and Indigenous organizations to cooperate, but Indigenous interests have not been considered by the states. Similarly, Spence (2017) argues that the balance of power in the AC benefits states. States have the ability to decide what issues will be put on the agenda, and when in the process other actors can contribute (Spence, 2017).

These two political phenomena observed in the AC, the lack of full representation among PPs and the dependency of Indigenous organizations on state actors, are interrelated. The question of what particular Indigenous nation is eligible to be represented as a PP was unclear since the beginning of discussions on Indigenous participation in the AC (English, 2013). As English (2013) notes, during the Rovaniemi meeting in 1989, the Russian and the American delegations expressed strongly their confusion about Indigenous representation. At that moment, the Arctic Indigenous groups in Russia were not organized, and only some of them associated themselves with the ICC. Similarly, Inuit represented only some Alaska Natives (English, 2013). The lack of a clear concept of who is Indigenous in the AC meant that member states were left to establish legal and political Indigenous status (Tennberg, 2000). According to Tennberg (2000), the legal definitions of Indigenous groups in national legislations were inherited by international lawmaking processes in the Arctic.

Meanwhile, in comparison with that of state actors, the level of participation of non-state actors in the $\mathrm{AC}$, including observers and PPs, is much lower (Knecht, 2017). Given the fact that the contribution of PPs is vital to discussions on changing Arctic conditions and traditional knowledge, the $\mathrm{AC}$ needs to discuss Indigenous representation as well as the degree of participation and commitment of other nonArctic actors (Knecht, 2017). The participation of PPs makes the $\mathrm{AC}$ unique among international governmental organizations (Gamble and Shadian, 2017). By including Indigenous peoples in international decision-making processes, the $\mathrm{AC}$ contributed to international regimebuilding (Gamble and Shadian, 2017).

An institutional reform of the AC to solve this problem of underrepresentation could involve a reconsideration of the legal concept of indigeneity. Because Indigenous legal and political identities are defined by national legislations of state-members, they differ significantly from each other.

A formal, legal description of indigeneity established by global transnational organizations defines Indigenous groups as "descendants of peoples who had inhabited the lands prior to colonization or conquest; their language and cultures are separate from national languages/culture of their countries" (Martinez-Cobo, 1982; UN Working Group on Indigenous Peoples, 1983; International Labor Organization, 1989; World Bank, 1991). However, as is clear in the example of Russia discussed below, not all Indigenous groups in the North are recognized legally as Indigenous. The institution of PPs was created to involve Indigenous communities in the discussion of important issues, such as environmental protection. The $\mathrm{AC}$ should reconsider the requirements and criteria for PPs by making them more flexible and inclusive of other Indigenous groups.

\section{VOICELESS:}

\section{OUTCOMES OF A DISTINCT RUSSIAN INDIGENEITY}

Territorial remoteness of circumpolar nations caused relatively late legal recognition of indigeneity in both Russia and North America. However, the conceptions of indigeneity of the North American Arctic Indigenous groups and the Russian northern Indigenous groups moved in quite different directions. Because of the radically distinct political ideologies and legal systems, the original peoples of Siberia and Arctic North America understand their indigeneity differently. As Table 1 shows, Russian and North American indigeneities have separate components that make their Indigenous status distinct.

The most significant difference in this comparison is the lack of recognition of Indigenous title in Russia. By admitting that Indigenous groups of Canada and the United States have the right to claim their lands, the American and Canadian governments agreed that European settlers colonized lands previously occupied by Indigenous groups (Zellen, 2008; Case and Voluck, 2012; Alcantara, 2013). The colonization of North America was much faster and more noticeable than in northeastern Europe or eastern Russia (Keskitalo, 2004; Øverland, 2009). 
TABLE 1. Comparison of the legal conceptions of indigeneity in northern Canada, Alaska, and the Russian Far North.

\begin{tabular}{|c|c|c|c|}
\hline $\begin{array}{l}\text { Historical overview of } \\
\text { Indigenous recognition }\end{array}$ & Canada & United States (Alaska) & Russia \\
\hline Time of recognition & - 1933 - Re Eskimos & $\begin{array}{l}\text { - } 1936 \text { - Indian Reorganization Act } \\
\text { (IRA) }\end{array}$ & $\begin{array}{l}\text { - } 1822 \text { (Speransky’s Decree) (all } \\
\text { Indigenous groups); } \\
\text { - } 1926 \text { - Statute about small- } \\
\text { numbered Indigenous peoples }\end{array}$ \\
\hline Reason for recognition & $\begin{array}{l}\text { - Canada's look to the North } \\
\text { - Early reports of missionaries about } \\
\text { miserable conditions among the } \\
\text { Inuit. } \\
\text { - Inuit recognized as equal to } \\
\text { Indigenous groups in Canada } \\
\text { - The process of decolonization after } \\
\text { the Second World War }\end{array}$ & $\begin{array}{l}\text { - Improvement in socioeconomic } \\
\text { conditions of Indigenous groups } \\
\text { (the IRA) } \\
\text { - Alaska Natives obtained } \\
\text { equal status with Indigenous } \\
\text { Americans }\end{array}$ & $\begin{array}{l}\text { - The necessity of governance over } \\
\text { all non-Slavic populations } \\
\text { - Threat of attack from the Asian } \\
\text { part of Russia } \\
\text { - New ethnic policy of the } \\
\text { Bolsheviks }\end{array}$ \\
\hline Governmental protection & $\begin{array}{l}\text { - } 1944 \text { - the Family Allowance } \\
\text { program }\end{array}$ & $\begin{array}{l}\text { - IRA ended the breakup of } \\
\text { reservations and allotment of lands } \\
\text { and encouraged tribes to adopt } \\
\text { constitutions for self-government }\end{array}$ & $\begin{array}{l}\text { - } 1822 \text { - no special protection was } \\
\text { designed } \\
\text { - } 1926 \text { - protection and special status } \\
\text { for small-numbered groups due to } \\
\text { their backwardness }\end{array}$ \\
\hline $\begin{array}{l}\text { Recognition of Indigenous } \\
\text { title and the right to autonomy }\end{array}$ & $\begin{array}{l}\text { - Indigenous title recognized by the } \\
\text { Calder decision } \\
\text { - Nunavut (public government) } \\
\text { created in } 1999 \text { as a result of land } \\
\text { claim negotiations }\end{array}$ & $\begin{array}{l}\text { - The Alaska Indigenous Claims } \\
\text { Settlement Act (1971) settled the } \\
\text { land claims of Alaska Natives }\end{array}$ & $\begin{array}{l}\text { - Indigenous title has never been } \\
\text { recognized } \\
\text { - Indigenous autonomies (public } \\
\text { governments) created as a result of } \\
\text { korenizatsiia policy in the } 1920 \mathrm{~s}\end{array}$ \\
\hline
\end{tabular}

In Russia, the Soviet government framed the legal concept of indigeneity with the intention of helping "backward" northern communities find their path to communism (Slezkine, 1994:421). Thus, the Soviet and then Russian governments were guided by the idea of protecting small nations from extinction (Slezkine, 1994), but they have never officially recognized the fact of colonization of their lands. Because of the lack of recognition of Aboriginal title by the Russians, Indigenous autonomies in the USSR/Russia were the product of the Soviet government and its ideology, and were not created as a result of land claim movements.

As Coulthard argues (2014), Indigenous-state relations are determined by the structure of domination. The voices of Indigenous groups are excluded from the legal and political systems of governance, so state actors use their power to determine the rights of Indigenous groups. The influence of state power can also be applied to the definition of indigeneity. In the legal and political sense, indigeneity is determined by domestic governments of states (Coulthard, 2014), so governments have the right to decide whom they want to see as Indigenous. The Russian government did not recognize the colonization of Siberia and the Far East of Russia, areas that were conquered during a slow and incremental process (Øverland, 2009). Unlike North America, Russia has seen Indigenous groups as small nations, people who need to be protected by the government (Pika, 1999). Indigenous groups not categorized as smallnumbered were considered "national minorities," e.g., nonethnic Russians (Laruelle, 2013:37).

The particular understanding and origins of indigeneity in Russia may lead to consequences that could significantly affect the discussion of Indigenous issues in the Arctic. Policymakers and other actors in the Arctic anticipate that the Russian understanding of indigeneity may create a situation in which not all Indigenous peoples in the Arctic are represented in the AC. Population increase may cause the loss of Indigenous status among small Arctic Indigenous groups. By becoming a larger Indigenous nation, some of the Arctic Indigenous minorities such as the Nenets could officially lose their Indigenous status. The loss of Indigenous status means that some of the former small groups will be excluded from RAIPON, and their representatives will no longer be able to participate in the $\mathrm{AC}$ as a part of the RAIPON.

The Russian legal conception of circumpolar indigeneity may also lead to positive political outcomes for the AC. Because of the historically derived principle of political autonomy and a large political representation among larger Indigenous nations, there is more access for Indigenous groups to participate in local decisionmaking processes. Because some regions have both larger and smaller Indigenous groups and are governed by the majority of Indigenous groups in the Parliament, this is a good opportunity for those nations who are represented in politics to advocate for Indigenous rights.

How do differences in the understanding of indigeneity in Russia and North America affect the AC? The AC should reconsider its formal requirements for the inclusion of Indigenous groups as PPs. The RAIPON represents only smaller Russian Indigenous groups, excluding larger Indigenous groups. Meanwhile, including larger Indigenous groups of the Arctic such as Sakha and Komi can bring new ideas and perspectives to the discussion of Indigenous and environmental issues. Indigenous groups from northern Russia who are not represented by RAIPON also have more political experience governing their regions, and they 
can affect the political decisions made in those areas. At this moment, Sakha and Komi are voiceless in the Arctic Council, but their inclusion as PPs could improve the political participation of Indigenous groups in the Arctic.

\section{ACKNOWLEDGEMENTS}

The author would like to thank Drs. Rob Huebert, Sabrina Peric, and Daniel Voth, as well as Ryan Dean, for their valuable comments and suggestions on various drafts.

\section{REFERENCES}

AC (Arctic Council). 1996. Declaration on the Establishment of the Arctic Council. Ottawa.

http://hdl.handle.net/11374/85

ACIA (Arctic Climate Impact Assessment). 2004. Impacts of a warming Arctic. Cambridge: Cambridge University Press. https://www.amap.no/documents/download/1058

Alcantara, C. 2013. Negotiating the deal: Comprehensive land claims agreements in Canada. Toronto: University of Toronto Press.

Anderson, R.T. 2007. Alaska Native rights, statehood, and unfinished business. Tulsa Law Review 43(1):17-41. http://digitalcommons.law.utulsa.edu/tlr/vol43/iss1/3

___ 2019. Arctic Council official website. https://arctic-council.org/index.php/en

Bankes, N. 2008. Legal and institutional framework: A comparative analysis. In: Mikkelsen, A., and Langhelle, O., eds. Arctic oil and gas: Sustainability at risk? Oxford and New York: Routledge. $111-138$.

Borisov A. 2014. The political status and ethnic identity of Siberian nomadic "aliens" in the first half of the 19 century. Tohoku University Bulletin 18:1-7.

https://tohoku.repo.nii.ac.jp/?action=repository_uri\&item id $=51203 \&$ file_id $=18 \&$ file_no $=1$

Byers, M. 2013. International law and the Arctic. Cambridge: Cambridge University Press. https://doi.org/10.1017/CBO9781107337442

Case, D.S., and Voluck, D.A. 2012. Alaska Natives and American laws, 3rd ed. Fairbanks: University of Alaska Press.

Consultant Plus. 1999. O garantiyah prav korennyh malochislennyh narodov Rossiyskoy Federatsii [About Indigenous smallnumbered peoples]. Federal Law from the State Duma of the Russian Federation. http://www.consultant.ru/document/cons_doc_LAW_22928/

Coulthard, G.S. 2014. Red skin, white masks: Rejecting the colonial politics of recognition. Minneapolis: University of Minnesota Press. https://doi.org/10.5749/minnesota/9780816679645.001.0001

Donahoe, B., Habeck, J.O., Halemba, A., and Sántha, I. 2008. Size and place in the construction of indigeneity in the Russian Federation. Current Anthropology 49(6):993-1020.

https://doi.org/10.1086/593014
English, J. 2013. Ice and water: Politics, peoples, and the Arctic Council. Toronto: Penguin Canada.

Gamble, J., and Shadian, J.M. 2017. One Arctic ... but uneven capacity: The Arctic Council Permanent Participants. In: Lackenbauer W., Nicol H., and Greaves W., eds. One Arctic: The Arctic Council and circumpolar governance. Ottawa: Canadian Arctic Resources Committee and the Centre on Foreign Policy \& Federalism. 142-156.

Heinämäki, L. 2009. Protecting the rights of Indigenous peoples Promoting the sustainability of the global environment? International Community Law Review 11(1):3 - 68. https://doi.org/10.1163/187197309X401406

Ingimundarson, V. 2014. Managing a contested region: The Arctic Council and the politics of Arctic governance. The Polar Journal 4(1):183-198.

https://doi.org/10.1080/2154896X.2014.913918

International Labour Organization. 1989. Indigenous and Tribal Peoples Convention, 1989 (No. 169).

https://www.ilo.org/dyn/normlex/en/f?p=NORMLEXPUB:12 100:0::NO::P12100_ILO_CODE:C169

Josephson, P.R. 2014. The conquest of the Russian Arctic. Cambridge, Massachusetts: Harvard University Press. https://doi.org/10.4159/harvard.9780674419827

Kahn, J. 2002. Federalism, democratization, and the rule of law in Russia. Oxford: Oxford University Press. https://doi.org/10.1093/0199246998.001.0001

Keskitalo, E.C.H. 2004. Negotiating the Arctic: The construction of an international region. London: Routledge.

Knecht, S. 2017. The politics of Arctic international cooperation: Introducing a dataset on stakeholder participation in Arctic Council meetings, 1998-2015. Cooperation and Conflict 52(2):203-223. https://doi.org/10.1177/0010836716652431

Laruelle, M. 2013. Russia's Arctic strategies and the future of the Far North. Armonk, New York: M.E. Sharpe.

Lindroth, M. 2015. Governing indigeneity globally: Indigenous peoples in the United Nations. Rovaniemi: University of Lapland.

Loukacheva, N. 2007. The Arctic promise: Legal and political autonomy of Greenland and Nunavut. Toronto: University of Toronto Press.

https://doi.org/10.3138/9781442684874

Martinez, J.R. 1982. Study of the problem of discrimination against Indigenous populations. Final report submitted by the Special Rapporteur. UN Doc E/CN.4/Sub.2/1982/Add.6.

Mason, A.M., Anderson, R., and Dana, L.-P. 2008. Oil and gas activities at the Mackenzie Delta, in Canada's Northwest Territories. In: Mikkelsen, A., and Langhelle, O., eds. Arctic oil and gas: Sustainability at risk? London: Routledge. 173-199.

McBeath, G.A., and Morehouse, T.A. 1994. Alaska politics and government. Lincoln: University of Nebraska Press.

Nilson, H.R. 1997. Arctic Environmental Protection Strategy (AEPS): Process and organization, 1991-97: An assessment. Research Report 103. Oslo: Norwegian Polar Institute. 
Nilsson, A.E. 2009. A changing Arctic climate: Science and policy in the Arctic Climate Impact Assessment. In: Koivurova, T., Keskitalo, E.C.H., and Bankes N., eds. Climate governance in the Arctic. Environment \& Policy, Vol. 50. Dordrecht, Netherlands: Springer Science+Business Media B.V. 77-95. https://doi.org/10.1007/978-1-4020-9542-9_4

Øverland, I. 2009. Indigenous rights in the Russian North. In: Rowe, E.W., ed. Russia and the North. Ottawa: University of Ottawa Press. 165-186.

Pika, A., ed. 1999. Neotraditionalism in the Russian North: Indigenous peoples and the legacy of perestroika. Edmonton, Alberta: Canadian Circumpolar Institute.

RAIPON (Russian Association of Indigenous Peoples of the North). 2019. RAIPON website. http://www.raipon.info/

Ross, C. 2002. Federalism and democratisation in Russia. Manchester: Manchester University Press.

Sakwa, R. 2008. Russian politics and society. London: Routledge.

Shadian, J.M. 2014. The politics of Arctic sovereignty: Oil, ice, and Inuit governance. Routledge Advances in International Relations and Global Politics, Vol. 115. London: Routledge.

Slezkine, Y. 1994. The USSR as a communal apartment, or how a socialist state promoted ethnic particularism. Slavic Review 53(2):414-452. https://doi.org/10.2307/2501300

Slocum, J.W. 1998. Who, and when, were the inorodtsy? The evolution of the category of "aliens" in imperial Russia. The Russian Review 57(2):173-190. https://doi.org/10.1111/0036-0341.00017

Smith, D.G. 1993. The emergence of "Eskimo Status": An examination of the Eskimo disk list system and its social consequences, 1925-1970. In: Dyck, N., and Waldram, J.B., eds. Anthropology, public policy, and Native peoples in Canada. Montreal: McGill-Queen's University Press. 41 - 74.
Spence, J. 2017. Is a melting Arctic making the Arctic Council too cool? Considering the credibility, saliency and legitimacy of a boundary organization. In: Lackenbauer W., Nicol H., and Greaves W., eds. One Arctic: The Arctic Council and circumpolar governance. Ottawa: Canadian Arctic Resources Committee and the Centre on Foreign Policy \& Federalism. $126-141$.

Stalin, J.V. 1913. Marxism and the national question. Provescheniye, Nos. 3-5.

https://www.marxists.org/reference/archive/stalin/ works/1913/03.htm

Tennberg, M. 2000. Arctic environmental cooperation: A study in governmentality. London: Routledge.

___ 2009. Indigenous peoples as international political actors: A summary. Polar Record 46(3):264-270. https://doi.org/10.1017/S0032247409990398

Wilson, E., and Øverland, I. 2007. Indigenous issues. In: Stokke, O.S., and Hønneland, G., eds. International cooperation and Arctic governance: Regime effectiveness and northern region building. London: Routledge. 27-49.

World Bank. 1991. Operational Directive 4.20. Indigenous Peoples.

https://www.ifc.org/wps/wcm/connect/835cc5004885 $5270 \mathrm{ab} 94 \mathrm{fb} 6 \mathrm{a} 6515 \mathrm{bb} 18 / \mathrm{OD} 420$ Indigenous Peoples. pdf?MOD=AJPERES

Xianzhong, L. 2014. Plyusy i minusy politiki "korenizatsii” SSSR v 1920-e gody [Pros and cons of "korenizatsiia" policy in the 1920s]. Oikumena 1:41-49. http://ojkum.ru/arc/lib/2014_01_05.pdf

Zellen, B.S. 2008. Breaking the ice: From land claims to tribal sovereignty in the Arctic. Lanham, Maryland: Lexington Books. 